\title{
IMPROVING FINANCIAL LITERACY AS A PREREQUISITE FOR INCREASING FISCAL CAPACITY: THE BULGARIAN CASE
}

\author{
Aleksandrina Aleksandrova ${ }^{1 *}$ and Taner Ismailov ${ }^{2}$ \\ ${ }^{1}$ Researcher R2, PhD, Tsenov Academy of Economics Svishtov, BULGARIA,a.alexandrova@uni- \\ svishtov.bg \\ ${ }^{2}$ Head Assist. Prof., PhD, Tsenov Academy of Economics Svishtov, BULGARIA,t.ismailov@uni- \\ svishtov.bg \\ ${ }^{\star}$ Corresponding Author
}

\begin{abstract}
Nowadays, the question of financial literacy and its interdependence with different aspects of the social and economic life of the state and citizens is being raised more often than ever. In the scientific field, numerous studies are exploring the relationship between the level of financial literacy of citizens and the financial decisions they make at different stages of their lives, according to their different needs. While in early studies of financial literacy researchers focused primarily on issues of personal finance administration and the level of basic financial knowledge, nowadays financial literacy is seen as a much broader and complex concept. The perceived individual need to make adequate financial decisions creates the need for specific financial knowledge and skills, i.e., financial literacy. Individual's responsibility for decision-making related to welfare, health and pension insurance, relationships with credit institutions and the state leads to the increasing and pressing need to improve financial literacy and incorporate (study) it in the educational processes.
\end{abstract}

An essential component in the process of making informed financial decisions and the resulting rights and obligations of citizens is the relationship with the state, i.e., the fiscal. Good knowledge of the structure of public finances, the tax system, the methods for calculating taxes due, etc. have a significant impact on this process. The current study aims to establish the level of financial literacy held by citizens and to test the research hypothesis that high financial literacy is a prerequisite for improving the country's fiscal capacity. For the purposes of the study, the authors have developed a unique survey, structured in 21 questions, conditionally divided into 3 groups. The survey analyses the results obtained by 266 respondents.

The first group (set) of questions aims to establish the level of financial literacy of the respondents and their attitude towards the need to study it. Based on self-assessment, the respondents indicate the level of their financial literacy, and the subsequent questions from the second group aim to test it. In the process of formulating the questions, the author's team follows the structure of OECD's survey questionnaire, conducted in 2019 on the financial literacy of the population of Southeast Europe. Emphasis is placed on issues related to the knowledge and understanding of the Bulgarian tax system, types of taxes, relations between citizens and the tax administration, etc., i.e. fiscal relations. These types of questions are essential to test the author's hypothesis. The third group of questions is focused on raising citizens' awareness of fiscal relations and assessing opportunities to improve the country's fiscal capacity through the application of various instruments by the tax administration. Improving the collection of taxes, paying the social security payments in full, creating preconditions for leaving the "grey sector" of more workers are fundamental for increasing the fiscal capacity of the state.

The results of the survey show that respondents have a relatively high financial literacy. However, they categorically state $(97.7 \%)$ that financial literacy needs to be studied in school and support the statement that if financially literate people predominate in a society, then society itself is financially stable ( $97.7 \%)$. Noteworthy, the respondents registered a significantly higher number of wrong answers on the questions focused on fiscal relations rather than on the ones concerning basic financial knowledge. The lack of deep and thorough knowledge of these relations has a direct impact on decision-making on tax planning, payment of taxes, social security contributions, etc., which in turn affects the fiscal capacity. The study assessed 
potential opportunities to raise awareness and improve financial literacy and, according to the survey's respondents, the most effective way would be the implementation of innovative digital tools disseminated through video streaming channels and social networks. It can be concluded that the state needs to put more effort into raising citizens' awareness of issues concerning fiscal relations in particular and financial literacy in general. The improvement of financial literacy must be the subject of a purposeful state policy and despite the measures taken by the Bulgarian state in this direction, survey respondents indicated a strong need to concentrate more efforts and resources. Considering the studied attitudes about financial literacy and its importance for increasing fiscal capacity, the author's team confirms its hypothesis.

Keywords: financial literacy, financial education, policy

\section{INTRODUCTION}

Financial literacy and the perceived necessity for its in-depth study are issues that are permanently increasing on the policymakers' agenda. Financial literacy and its interdependence with various aspects of the social and economic life of the state and citizens is a research subject of many authors scientific searches worldwide. In the last decade, developed and emerging economies have become increasingly aware of the importance of ensuring that their citizens are financially literate (Salas-Velasco, MorenoHerrero, \& Sanchez-Campillo, 2021). In the scientific field, there are many studies focused on the relationship between citizens' financial literacy proficiency and financial decisions that they make at different stages of their lives, according to their different needs. It has dramatical implications on financially personal decisions making (Kezar \& Yang, 2010); (Lusardi \& Mitchell, 2014); (Maturana \& Nickerson, 2018); (Paiella, 2016); (Rashidin, Javed, Chen, \& Jian, 2020). While in early studies of financial literacy, researchers focused on issues of personal finance administration and basic financial knowledge, nowadays financial literacy is considered a more comprehensive concept. Researchers associate financial literacy with economics (Berti, 2016); (Aprea, et al., 2016) (Retzmann \& Seeber, 2016) and different forms of citizenship education (Björklund \& Sandahl, 2020); (Davies, 2015). Financial literacy of the population is a complex concept. In a broad sense, it is about the ability of the population to rationally manage the finances of households (keep records of income and expenditure, competently implement short-term and long-term financial planning), being aware on the state of legislation and the situation in financial markets and to understand the features of various financial products and services (Ivanova, Bogoslavtseva, Karepina, \& Kostoglodova, 2017). Many financial literacy educational efforts mainly focus on teaching money management. However, money management alone does not address financial prerequisites concerning home ownership, savings or retirement planning since these issues are governed by agents outside households, namely the financial system and policy makers (Björklund \& Sandahl, 2021). The perceived need for each individual to make an adequate financial decision brings the need for specific financial knowledge and skills, i.e. financial literacy. Since contemporary societies leave the individual responsible for choosing and defraying housing, healthcare and pensions, the ability to interact with the financial system is considered an important competence for all (Retzmann \& Seeber, 2016). The Organisation for Economic Co-operation and Development (OECD), along with many national educational frameworks and curricula seem to promote financial literacy teaching and learning that mainly focus on money management (Björklund \& Sandahl, 2021), such as income and expenditure (Bosshardt \& Walstad, 2014) (Bosshardt \& Caltabiano, 2013); (Menzies \& Wood, 2012); (OECD, 2018); (OECD/INFE, 2015); (Tisdell, Taylor, \& Forte, 2013), along with a message of prudence concerning loans and mortgages (Lucey \& Bates, 2012). Financial education improves people's understanding of different financial products and concepts through various instructions, information, and advice to develop financial risks and opportunities recognition skills. (Ministry of Finance, 2021).

An essential component of the process of making informed financial decisions and the resulting citizens' rights and obligations is their relationship with the state, i.e. the fiscus. Financial literacy has a strong link with the development of every country's financial systems (Hasan, Le, \& Hoque, 2021). The concept of financial literacy covers fiscal and taxation literacy (Vovchenko, Galazova, Danchenko, Ivanova, \& Kostoglodova, 2018). Fiscal literacy is associated with the accumulation of basic knowledge about the legal framework governing budgetary procedure, budget structure, its purpose, budget revenue sources and budget expenditure structure. Taxation literacy should be regarded as a necessary competence of modern man which ensures the effective use of financial resources and allows preventing the realization of risks of income losses, reputation and freedom of the taxpayer (Vovchenko, Galazova, Danchenko, Ivanova, \& Kostoglodova, 2018). Good knowledge of the public finance structure, the tax system, the methods for calculating taxes due, etc. significantly impacts the process of financial decision-making by citizens, which in 
turn has a direct impact on the economic development of the state.

\section{RESEARCH METHODOLOGY}

This research aims to define the level of financial literacy and to confirm or disprove the research hypothesis that high financial literacy is a prerequisite for improving the country's fiscal capacity. The study analyses financial perceptions and skills (financial literacy) in a group of 266 people, located in Bulgaria. The approach is quantitative, non-experimental, cross-sectional, and descriptive and is framed within an analytical empirical paradigm. The questionnaire survey is self-administered, a hyperlink to the questionnaire is sent to over 1000 people, and 266 willing respondents completed the survey. These 266 respondents formed the research's voluntary response sample. A 21 question survey (containing single-answer multiple-choice questions, matrix questions and Likert-type questions) is applied and divided into three groups. The first group of questions aims to establish the level of financial literacy of the respondents and their attitude towards the need to study it. Based on self-assessment, the respondents indicate the level of their financial literacy, and the subsequent questions from the second group aim to test it. In the process of formulating the questions, the author's team follows the structure of OECD's survey questionnaire, conducted in 2019 on the financial literacy of the population of Southeast Europe. The team also use public and easily accessible information from the websites of the Bulgarian Ministry of Finance and the Bulgarian National Revenue Agency while formulating the questions. Emphasis is placed on issues related to the knowledge and understanding of the Bulgarian tax system, types of taxes, relations between citizens and the tax administration, etc., i.e. fiscal relations and fiscal literacy. These types of questions are essential to test the authors' hypothesis. The third group of questions is focused on raising citizens' awareness of fiscal relations and assessing opportunities to improve the country's fiscal capacity through the application of various instruments by the tax administration. Improving the collection of taxes, paying the social security payments in full, creating preconditions for leaving the "grey sector" of more workers are fundamental for increasing the fiscal capacity of the state.

\section{RESULTS}

The first three questions from the first group are focused on collecting information on the socio-demographic structure of the respondents. From the data provided and processed it comes clear that $54.9 \%$ of the respondents are in the age group 30-45 years, $27.1 \%$ - from 20 to 29 years, $15 \%$ fall into the group from 46 to 65 years, 1, 9\% are under the age of 20 and $1.1 \%$ - over the age of 65 . From the above information on the age structure of the respondents, it follows that over $95 \%$ fall into the group of the working-age population.

Regarding the education held by the respondents, it is clear from the processed data that $43.2 \%$ of the respondents hold a Master's degree, 27.1\% - a Bachelor's degree; $27.1 \%$ hold High school education Diploma, $6.4 \%$ hold a PhD degree and 1.5\% hold Primary Education Diploma. The information presented in this way allows us to summarize that $76.7 \%$ of the respondents have higher education. This fact is essential in determining financial understanding, as the scientific literature on the problem often emphasizes the relationship between high education and high financial literacy. Higher education implies a relatively good level of financial literacy or a perceived need to improve it. The last of the questions focused on the sociodemographic structure of the respondents is related to the field of their professional realization. $31.6 \%$ are employed in the private business and entrepreneurship, 33.5\% - in the public sector, $15.8 \%$ in the corporate sector, and $12.4 \%$ are not employed at the time of the survey.

The next two questions aim to determine whether respondents have studied financial literacy disciplines during their training and what is level of financial literacy they have, based on their self-assessment. 82.7\% of the respondents answered that during their education they studied disciplines related to financial literacy, while $17.3 \%$ did not. To the question "How do you rate your financial literacy?" $11.7 \%$ think it is excellent, $37.6 \%$ - very good, 38.3\% - good, $10.9 \%$ - basic and 1, 5\% answer that they do not have any financial literacy. Interestingly, $17.3 \%$ of respondents did not study any financial literacy courses, but only $1.5 \%$ of the 266 respondents believe that they do not have any financial literacy.

The last two questions from the first group aim to establish the attitudes of the respondents about the relationship between financial literacy and the financial stability of society. To the question: 'Do you agree with the following statement: Financially literate people are more responsible and better prepared to plan their economic and financial future. If financially literate people predominate in a society, then the society itself is more financially stable.' $97.4 \%$ of the respondents answered in the affirmative. To the following question: 'Do you agree with the following statement: Financially literate people are aware of the amount of tax burden they bear and the methods for calculating it.' $91 \%$ of respondents. From the above data, it can be concluded that the respondents strongly share the opinion and attitude that there is a direct relationship 
between financial literacy and financial stability of society, i.e. a high level of financial literacy is a prerequisite for improving the welfare of society.

The last two questions from the first group aim to understand the attitudes of the respondents about the relationship between financial literacy and the financial stability of society. To the question: 'Do you agree with the following statement: Financially literate people are more responsible and better prepared to plan their economic and financial future. If financially literate people predominate in a society, then the society itself is more financially stable' $97.4 \%$ of the respondents answered in the affirmative. To the question: 'Do you agree with the following statement: 'Financially literate people are aware of the amount of tax burden they bear and the methods for calculating it.' $91 \%$ of respondents answered confirmative. From the data above, can be concluded that the respondents strongly share the opinion and attitude that there is a direct relationship between financial literacy and financial stability of society, i.e. a high level of financial literacy is a prerequisite for improving the welfare of society.

The second group of questions aims to examine respondents' financial literacy knowledge. In selecting the questions, the team borrowed two questions from the OECD's survey questionnaire, conducted in 2019 on the financial literacy of the population of Southeast Europe. The first and second questions from this group are part of the OECD's survey and were selected because they aim to test respondents' basic knowledge of fundamental financial and economic categories such as lending and inflation. To the question: 'You lend BGN 25 to a friend on Monday night and Tuesday morning he returns BGN 25. What is the amount of interest that your friend has paid on this loan?' with a choice of answers: $0 \% ; 1 \%$ and $100 \%-96.2 \%$ of the respondents indicate the correct answer - $0 \%, 1.9 \%$ of the respondents indicate $1 \%$ and $1.9 \%$ indicate $100 \%$. To the question: 'Do you agree with the statement that: 'High inflation means that the cost of living is rising rapidly.' - $89.1 \%$ of the respondents answered positively, which is the correct answer, and $10.9 \%$ of the respondents answered this question incorrectly.

Subsequent questions in this group focus on fiscal relations and in more specifically on fiscal and tax literacy. They are based on easily accessible, public information from the official websites of the Bulgarian Ministry of Finance and the Bulgarian National Revenue Agency. Their purpose is to establish the depth of the respondents' knowledge in the field of taxation, tax administration, fiscal relations, etc. The team also formulated two misleading questions. To the question: 'Do you agree with the statement: I am aware of the structure of the Bulgarian tax system and the types of taxes it covers.', $63.5 \%$ of the respondents answered positively, $34.2 \%$ answered that they are not, but $2.3 \%$ think they are aware "to some extent". It is noteworthy that when asked about the overall financial literacy of the first group, $87.6 \%$ of respondents believe that they have a good or higher level of financial literacy, but when the focus is on two of its components such as fiscal or tax literacy share of respondents claiming to have such, decreased significantly to $63.5 \%$. The following questions from this group test basic knowledge in the field of taxation, tax rates and tax legislation in Bulgaria, and they are formulated based on the most frequently asked questions to the Bulgarian National Revenue Agency, published on the official website of the Agency. To the question: 'Do you agree with the statement that: As an end-user, you pay value-added tax in the amount of $20 \%$ of the value for each product or service you consume (except for the exceptions provided for in the VAT Act).' $91 \%$ of the respondents answered positively and $9 \%$ answered "No". The fact that $9 \%$ of respondents answer this question incorrectly raises researchers' attention because the incorrect answer to this question means that $9 \%$ of respondents lack basic financial knowledge related to the daily consumption of goods and services. The next question in the survey is related to the "civil contract" or the contract for the performance of a certain service, the taxation under this legal relationship and the obligation of the persons who have concluded such a contract to file an annual tax return. $84.6 \%$ of the respondents answered this question correctly. One of the most common sources of income for individuals from non-employment relationships is rental income. For this reason, the research team composed a question focused on this income. To the question: 'Do you agree with the statement: Rental income (rent) is a source of income. You declare the rent received in an annual tax declaration and the tax rate is $10 \%$.' $88 \%$ of the respondents answered "Yes", which is the correct answer, while $7.1 \%$ answered incorrectly and $4.9 \%$ said they were not familiar with the answer.

The last three questions from this group are more specific and each of them contains misleading information. Their purpose is to test not only the knowledge of the respondents but their ability for their analytical application in the context of fiscal and tax literacy, e.g. financial literacy. In the question: 'Do you agree with the statement that: You must declare your income to the NRA if you receive income only from employment and as of December 31 of the year in which you receive the income, your employer has determined the annual amount of tax for the income acquired during the year from you and has withheld and paid the full amount of the tax for the respective year until January 31 of the following year.'. Of the respondents, $51.9 \%$ 
answered "Yes", which in this case is the wrong answer, 46.2\% answered the question correctly, and $1.9 \%$ wrote that they did not know the answer. To the next question: 'Do you agree with the statement: The amount of the tax rate for corporate tax in the Republic of Bulgaria is $20 \%$.' $^{\prime} 55.6 \%$ answered that they agree, which is a wrong answer because the tax rate for this tax according to the Bulgarian legislation is $10 \%$. Correct to this question was answered by $40.6 \%$ of respondents, and $3.8 \%$ said they did not know the answer. The last question from the second group is related to the tax rate for personal income taxation in Bulgaria, which is $10 \%$. To the question: 'According to the Personal Income Tax Act, the amount of tax rate for individuals' personal income tax is:' there are three possible answer options - $10 \% ; 15 \%$ and $20 \%$. $77.1 \%$ of the respondents answered this question correctly, and $22.9 \%$ gave the wrong answer. From the data above, it comes clear that with the increasing difficulty of questions about fiscal relations and the need for more in-depth knowledge in the field of fiscal literacy and tax literacy, as well as the application of an analytical approach to answering, the share of respondents who give wrong answers. The analyzed data show that not only is there a lack of knowledge about basic tax categories, but also skills for applying financial knowledge in general.

The third and final group of questions from the survey aims to examine the attitudes of respondents about the need to study financial literacy in school education and raise respondents' awareness of fiscal relations and assessing opportunities to improve the country's fiscal capacity. To the question: 'Do you think that it is necessary to study financial literacy in school education?' - 98.1\% of the respondents categorically confirm that it is necessary against only $1.9 \%$, who answered negatively. The next question is related to the attitudes of citizens towards raising their awareness and thus reducing the number of people working in the "grey" sector of the economy. To the question: 'Do you think that raising citizens' awareness of the tax burden and the potential benefits of declaring and paying their full amount, in the long run, will create the conditions for more people to leave the" grey sector "?' - 70, 7\% of the respondents answered positively, $19.5 \%$ negatively and $9.8 \%$ could not judge. This means that, according to citizens, raising awareness is one of the key factors in improving financial literacy.

The last three questions from the survey are related to the attitudes of the respondents about the possibility of increasing financial literacy, and hence the fiscal capacity of the country. Two of them are Likert-type questions and one matrix question and they aim to study the attitudes of the respondents about the effectiveness of various methods for raising their awareness and the application of digital tools to improve financial literacy and tax collection. The table represents the answers to the question about raising awareness and its relationship with increasing tax collection. In both cases, $61.28 \%$ and $60.90 \%$ of the respondents believe that raising the awareness of the citizens will have a positive impact on the collection of taxes in the state and local budgets.

Table 1. Perceptions on raising citizens' awareness of the tax system, tax rates, taxation etc. financial literacy components and its relation to creating conditions for increasing tax collection

\begin{tabular}{|l|r|r|r|}
\hline $\begin{array}{l}\text { Do you believe by raising citizens' awareness of the tax system, tax rates, } \\
\text { taxation etc. financial literacy components will create conditions for } \\
\text { increasing collection of the following taxes (tax revenue): }\end{array}$ & Yes & No & $\begin{array}{c}\text { I can't } \\
\text { answer }\end{array}$ \\
\hline $\begin{array}{l}\text { Taxes collected in the State budget (eg value added tax, excise duties, } \\
\text { corporate tax, personal income taxes) }\end{array}$ & 61,28 & 20,68 & 18,05 \\
\hline $\begin{array}{l}\text { Taxes collected in local budgets (eg inheritance tax, patent tax, tourist tax, } \\
\text { etc.) }\end{array}$ & 60,90 & 23,68 & 15,41 \\
\hline
\end{tabular}

Of particular interest to the authors is the answer to the question: 'In your opinion, how effective are the following methods for raising citizens' awareness and improving their financial literacy in the field of the tax system and taxation?'. According to the answers given, the most effective tool to be applied is the most traditional one - on-site consultations in tax administration units with tax officers (Table 2). They are placed next to the introduction of a single electronic information portal for individuals and legal entities, uniting the activities of the National Revenue Agency, the Ministry of Finance and the local tax administrative units that concern citizens and businesses and creation of short explanatory videos containing most frequently occurring cases for individuals and legal entities and uploading them to the Youtube platform and social networks. 
Table 2. Effectiveness of methods for raising citizens' awareness and improving their financial literacy in the field of the tax system and taxation

\begin{tabular}{|l|l|l|l|l|l|}
\hline $\begin{array}{l}\text { In your opinion, how effective are the } \\
\text { following methods for raising citizens' } \\
\text { awareness and improving their financial } \\
\text { literacy in the field of the tax system and } \\
\text { taxation: }\end{array}$ & $\begin{array}{c}\text { Very } \\
\text { effective }\end{array}$ & Effective & $\begin{array}{c}\text { Neither } \\
\text { effective } \\
\text { nor } \\
\text { ineffective }\end{array}$ & $\begin{array}{c}\text { Low } \\
\text { effective }\end{array}$ & $\begin{array}{c}\text { Not at all } \\
\text { effective }\end{array}$ \\
\hline $\begin{array}{l}\text { Written explanations of the most frequently } \\
\text { asked questions to the tax authorities by } \\
\text { individuals and legal entities, published on } \\
\text { the official website of the NRA, the Ministry } \\
\text { of Finance and the websites of the local } \\
\text { territorial units (regional centers, } \\
\text { municipalities, etc.) }\end{array}$ & 35,34 & 42,86 & 6,39 & 12,41 & 3,01 \\
\hline $\begin{array}{l}\text { Introduction of a single electronic } \\
\text { information portal for individuals and legal } \\
\text { entities, uniting the activities of the National } \\
\text { Revenue Agency, the Ministry of Finance } \\
\text { and the local tax administrative units that } \\
\text { concern citizens and businesses }\end{array}$ & 53,01 & 35,34 & 7,14 & 2,63 & 1,88 \\
\hline $\begin{array}{l}\text { Creation of short explanatory videos } \\
\text { containing most frequently occurring cases } \\
\text { for individuals and legal entities and } \\
\text { uploading them to the Youtube platform and } \\
\text { social networks }\end{array}$ & 51,88 & 34,59 & 10,15 & 2,26 & 1,13 \\
\hline $\begin{array}{l}\text { Correspondence by email or telephone with } \\
\text { tax administration representatives }\end{array}$ & 50,00 & 33,08 & 7,89 & 6,02 & 3,01 \\
\hline $\begin{array}{l}\text { On-site consultations in tax administration } \\
\text { units with tax officers }\end{array}$ & 57,89 & 27,44 & 7,89 & 5,26 & 1,50 \\
\hline
\end{tabular}

In the context of digitalization and the digital society, the authors question the effectiveness of digital tools for improving citizens' financial literacy and increasing (national and local) taxes collection (Table 3). Respondents categorize as most effective online calculators for calculating potential fines and penalties imposed by the tax authorities for non-payment of taxes due within a certain period $(66,9 \%)$, reminders and alerts about upcoming deadlines for paying taxes and fees due, by synchronizing calendars (e.g. Google Calendar, Outlook calendar) $(66,54 \%)$ and online calculators for calculating the amount of taxes and fees due $(66,54 \%)$. It is impressive that respondents strongly consider these digital tools to be effective and assess their impact on financial literacy and tax collection extremely high. This statement is validated by the extremely low percentage of respondents who believe digital tools are ineffective.

Table 3. Effectiveness of digital tools for improving citizens' financial literacy and increasing tax collection

\begin{tabular}{|l|r|r|r|r|r|}
\hline $\begin{array}{l}\text { In your opinion, how effective are the } \\
\text { following digital tools for improving citizens } \\
\text { financial literacy and increasing (national } \\
\text { and local) taxes collection? }\end{array}$ & $\begin{array}{c}\text { Very } \\
\text { effective }\end{array}$ & Effective & $\begin{array}{c}\text { Neither } \\
\text { effective } \\
\text { nor } \\
\text { ineffective }\end{array}$ & $\begin{array}{r}\text { Low } \\
\text { effective }\end{array}$ & $\begin{array}{l}\text { Not at all } \\
\text { effective }\end{array}$ \\
\hline $\begin{array}{l}\text { Online calculators for calculating the } \\
\text { amount of taxes and fees due }\end{array}$ & 66,54 & 29,32 & 2,26 & 1,50 & 0,38 \\
\hline
\end{tabular}




\begin{tabular}{|l|r|r|r|r|r|}
\hline $\begin{array}{l}\text { Simulators for filling in mandatory tax } \\
\text { documents and files (e.g. tax declaration/ } \\
\text { tax return etc.) }\end{array}$ & 61,28 & 33,08 & 3,01 & 2,26 & 0,38 \\
\hline $\begin{array}{l}\text { Reminders and alerts about upcoming } \\
\text { deadlines for paying taxes and fees due, } \\
\text { by synchronizing calendars (e.g. Google } \\
\text { Calendar, Outlook calendar) }\end{array}$ & 66,54 & 30,08 & 2,26 & 1,13 & 0,00 \\
\hline $\begin{array}{l}\text { Online calculators for calculating potential } \\
\text { fines and penalties imposed by the tax } \\
\text { authorities for non-payment of taxes due } \\
\text { within a certain period. }\end{array}$ & 66,92 & 27,82 & 2,63 & 1,50 & 1,13 \\
\hline
\end{tabular}

\section{CONCLUSIONS}

The results of the survey suggest that respondents have a relatively high financial literacy. However, they categorically state $(97.7 \%)$ that financial literacy needs to be studied in school and support the statement that if financially literate people predominate in a society, then society itself is financially stable (97.7\%). These results confirm OECD's policy recommendations regarding financial education that needs to be used as a supporting policy to economic and financial reforms, for example aimed at improving financial systems stability and consumer confidence (OECD, 2020). Noteworthy, the respondents claimed a significantly higher number of wrong answers on the questions focused on fiscal relations rather than on the ones concerning basic financial knowledge. The lack of deep and thorough knowledge of these relations has a direct impact on decision-making on tax planning, payment of taxes, social security contributions, etc., which in turn affects the fiscal capacity. The study assessed potential opportunities to raise awareness and improve financial literacy and, according to the survey's respondents, the most effective way would be the implementation of innovative digital tools. Respondents suggest the need to strengthen financial education policies and develop policy tools, including digital technologies or behavioral insights, for instance, which could be further harnessed to improve financial knowledge and behavior conducive to enhanced individual financial resilience (OECD, 2020). It can be concluded that the state needs to put more effort into raising citizens' awareness of issues concerning fiscal relations in particular and financial literacy in general. Considering the studied attitudes about financial literacy and its importance for increasing fiscal capacity, the author's team confirms its hypothesis. The improvement of financial literacy must be the subject of a purposeful state policy and despite the measures taken by the Bulgarian state in this direction, survey respondents indicated a strong need to concentrate more efforts and resources.

\section{ACKNOWLEDGEMENT}

This research was financially supported by the project, which has received funding from the The National Science Fund at the Bulgarian Ministry of Education and Science, Funding Competition for financial support for projects of junior basic researchers and postdocs - 2019, No. КП-06 M35/5 from 18/12/2019, "Fiscal discipline and/or growing the fiscal capacity of the Republic of Bulgaria?", Project coordinator: Aleksandrina Aleksandrova, PhD.

\section{REFERENCE LIST}

Aprea, C., Wuttke, E., Breuer, K., Koh, N. K., Davies, P., Fuhrmann, B., \& Lopus, J. S. (2016). Approaches the field of financial literacy from various scientific angles such as development, assessment, training. International Handbook of Financial Literacy, 1-4. doi:10.1007/978-981-10-0360-8

Berti, A. E. (2016). Sketching a Possible Learning Progression for the Cognitive Component of Financial Education in the Broader Context of Economic Education. International Handbook of Financial Literacy, 515-530. doi:10.1007/978-981-10-0360-8_33

Björklund, M., \& Sandahl, J. (2020). Financial Literacy as Citizenship Education - a viable prospect? JSSE Journal of Social Science Education, 4-20. doi:10.4119/jsse-3230 
Björklund, M., \& Sandahl, J. (2021). Inviting students to independent judgement: Teaching financial literacy as citizenship education. Citizenship, Social and Economics Education, 103-121. doi:10.1177/20471734211029494

Bosshardt, W., \& Caltabiano, C. (2013). National Standards for Financial Literacy. New York: USA: Council for Economic Education.

Bosshardt, W., \& Walstad, W. B. (2014). National Standards for Financial Literacy: Rationale and Content. The Journal of Economic Education, 63-70. doi:10.1080/00220485.2014.859963

Davies, P. (2015). Towards a framework for financial literacy in the context of democracy. Journal of Curriculum Studies, 300-316. doi:10.1080/00220272.2014.934717

Hasan, M., Le, T., \& Hoque, A. (2021). How does financial literacy impact on inclusive finance? Financial Innovation. doi:10.1186/s40854-021-00259-9

Ivanova, O. B., Bogoslavtseva, L. V., Karepina, O. I., \& Kostoglodova, E. D. (2017). Providing the Budget Transparency and State Projects Efficiency Monitoring in Russia. European Research Studies Journal, 97-104. doi:10.35808/ersj/599

Kezar, A., \& Yang, H. (2010). The Importance of Financial Literacy. SAGE Journals, 6(14), 15-21. doi:10.1002/abc.20004

Lucey, T. A., \& Bates, A. B. (2012). Conceptually and Developmentally Appropriate Education for Financially Literate Global Citizens. Citizenship, Social and Economics Education, 160-162. doi:10.2304/csee.2012.11.3.160

Lusardi, A., \& Mitchell, O. S. (2014). The Economic Importance of Financial Literacy: Theory and Evidence. Journal of Economic Literature, 1(52), 5-44. doi:10.1257/jel.52.1.5

Maturana, G., \& Nickerson, J. (2018). Teachers Teaching Teachers: The Role of Workplace Peer Effects in Financial Decisions. The Review of Financial Studies, 10(32), 3920-3957. doi:10.1093/rfs/hhy136

Menzies, M., \& Wood, P. (2012). Charting a Course: A Review of Financial Education in New Zealand. Wellington: New Zeeland: Commission for Financial Literacy and Retirement Income.

Ministry of Finance. (2021, 09). Retrieved from REPUBLIC OF BULGARIA, Ministry of Finance, Official website, : https://www.minfin.bg/en/1489

OECD (2020), F. L. (2020). Financial Literacy of Adults in South East Europe. Retrieved from www.oecd.org: www.oecd.org/daf/fin/financial-education/south-east-europe-financial-education.htm

OECD. (2018). PISA 2018 Released Financial Literacy Items. PARIS: FRANCE: OECD.

OECD/INFE. (2015). National Strategies for Financial Education OECD/INFE Policy Handbook. PARIS: FRANCE: OECD publishing.

Paiella, M. (2016). Financial literacy and subjective expectations questions: A validation exercise. Research in Economics, 2(70), 360-374. doi:10.1016/j.rie.2015.11.004

Rashidin, M. S., Javed, S., Chen, L., \& Jian, W. (2020). Assessing the Competitiveness of Chinese Multinational Enterprises Development: Evidence From Electronics Sector. SAGE Journal, 1-20. doi:10.1177/2158244019898214

Retzmann, T., \& Seeber, G. (2016). Financial Education in General Education Schools: A Competence Model. International Handbook of Financial Literacy, 9-23. doi:10.1007/978-981-10-0360-8_2

Salas-Velasco, M., Moreno-Herrero, D., \& Sanchez-Campillo, J. (2021, July). Teaching financial education in schools and students' financial literacy: A cross-country analysis with PISA data(Article). International Journal of Finance and Economics, 3(26), 4077-4103. doi:10.1002/ijfe.2005

Tisdell, E. J., Taylor, E. W., \& Forte, K. S. (2013). Community-Based Financial Literacy Education in a Cultural Context: A Study of Teacher Beliefs and Pedagogical Practice. SAGE Journals, 338-356. doi:10.1177/0741713613477186

Vovchenko, N. G., Galazova, S. S., Danchenko, E. A., Ivanova, O. B., \& Kostoglodova, E. D. (2018). Improvement of Financial Literacy as a Crucial Factor of Economic Development. European Research Studies Journal, 16-24. doi:10.35808/ersj/1154 